\title{
Teknik Identifikasi Program Paket C dalam Meningkatkan Keterampilan Fungsional Warga Belajar
}

\author{
Ahmad Syahid ${ }^{\bowtie}$ \\ Program Studi Pendidikan Luar Sekolah FKIP Universitas Singaperbangsa Karawang
}

\begin{tabular}{l}
\hline Info Artikel \\
\hline Sejarah Artikel: \\
Diterima April 2017 \\
Disetujui Mei 2017 \\
Dipublikasikan Juni 2017
\end{tabular}

Keywords:

identification techniques; paket C program; functional skills

\begin{abstract}
Abstrak
Tujuan penelitian ini menganalisis tentang teknik identifikasi kebutuhan belajar program Paket $\mathrm{C}$, dan peningkatan keterampilan fungsional warga belajar Paket C di PKBM Buana Mekar. Penelitian dilakukan menggunakan pendekatan kualitatif dengan metode studi kasus untuk mendeskripsikan pembelajaran kewirausahaan untuk pemberdayaan kelompok pemuda produktif. Subyek penelitiannya satu orang pengelola $\mathrm{PKBM}$, satu orang tutor dan tiga orang warga belajar Paket C. Pengumpulan data menggunakan teknik observasi, wawancara mendalam, dan analisis dokumentasi. Tahapan penelitian melalui tahap: orientasi, eksplorasi, dan member check. Analisis data menggunakan model interaktif melalui langkah-langkah: koleksi data, reduksi data, penyajian data, dan penarikan kesimpulan/verifikasi. Hasil penelitian menyimpulkan tujuan identifikasi program Paket C untuk menyusun kebutuhan belajar, perencanaan, proses, penentuan waktu, penyediaan sarana, dan media pembelajaran. Teknik identifikasi menggunakan Kartu SKBM, wawancara, angket, observasi, pertemuan kelompok, dan teknik indikator sosial. Hasil pembelajaran Paket $C$ berbasis keterampilan fungsional menekankan pada pengembangan pengetahuan, sikap dan keterampilan kewirausahaan.
\end{abstract}

\begin{abstract}
The purpose of this research is to analyze the learning needs identification technique of Paket $C$ program, and to improve the functional skills of the Paket $C$ learners at CLC Buana Mekar. The study was conducted using a qualitative approach with case study methods to describe entrepreneurial learning for empowering productive youth groups. The subjects of the research were one CLC manager, one tutor and three learners of Paket $C$. Data collection using observation techniques, in-depth interviews, and documentation analysis. Stages of research through the stage: orientation, exploration, and member check. Data analysis uses interactive models through the steps: data collection, data reduction, data presentation, and conclusion/verification. The result of the research concludes the purpose of identification of Paket $C$ program to compile the learning needs, planning, process, timing, provision of facilities, and instructional media. Identification techniques using SKBM Cards, interviews, questionnaires, observations, group meetings, and social indicator techniques. Learning outcomes Paket $C$ based on functional skills emphasizes the development of knowledge, attitudes and entrepreneurial skills.
\end{abstract}

Alamat korespondensi:

E-mail: aameth9@gmail.com 


\section{PENDAHULUAN}

Dewasa ini masyarakat di samping sebagai konsumen pendidikan luar sekolah juga dapat menjadi produsen dari pada tenaga-tenaga pendidikan luar sekolah. Dikatakan demikian, karena masyarakat sendiri terdiri dari bermacam- macam kelompok individu dengan taraf hidup serta peranan yang berbeda-beda. Masyarakat juga menjadi ajang terjadinya berbagai peristiwa yang saling berpengaruh terhadap pola-pola tingkah laku dan kehidupan manusia. Di dalam masyarakat terdapat minatminat, kebutuhan-kebutuhan dan tujuan-tujuan hidup yang berbeda-beda, dan bahkan sering terjadi konflik antar nilai, antar kepentingan dan antar tujuan hidup dari para anggota masyarakat tersebut. Dengan demikian, masyarakat juga merupakan faktor penghambat dari usaha-usaha memajukan hidup manusia.

Meskipun sumber daya alam cukup tersedia sebagai alternatif lain untuk diolah dan dijadikan lapangan kerja, akan tetapi pendayagunaan sumber daya alam tersebut belum optimal. Sehubungan belum adanya tenaga kerja yang andal serta profesional dalam pengolahan sumber daya alam tersebut. Perkembangan jumlah penduduk dan jumlah angkatan kerja tanpa diikuti pertumbuhan lapangan kerja, serta terbatasnya pengetahuan dan keterampilan angkatan kerja, atau ketidaksesuaian antara pengetahuan serta keterampilan dengan kebutuhan pasar kerja, telah menjadi permasalahan yang sangat kompleks dan signifikan.

Seperti diketahui bahwa salah satu orientasi pendidikan nonformal (PNF) yang berintegrasi diarahkan kepada keterampilan fungsional, dewasa ini berbagai upaya dilakukan oleh lembaga-lembaga yang terkait, seperti Dinas Pendidikan melalui Subdinas PNFI telah menyelenggarakan program Kejar Paket C berbasis keterampilan fungsional. Kondisi inilah yang terjadi pada PKBM Buana Mekar Kecamatan Tegalwaru Kabupaten Karawang. Di PKBM tersebut kini terdapat kurang lebih 40 orang warga belajar yang mengikuti pembelajaran keterampilan fungsional yang berbasis pada potensi lokal.
Dalam perkembangannya, pembelajaran keterampilan fungsional warga belajar Kejar Paket C di PKBM Buana Mekar dilaksanakan dalam upaya menumbuhkembangkan jiwa wirausaha. Melalui pembelajaran keterampilan fungsional ini diharapkan warga belajar Kejar Paket C di PKBM Buana Mekar dapat memiliki kemampuan keterampilan untuk berwirausaha secara maksimal. Pembelajaran keterampilan fungsional bagi warga belajar Kejar Paket C di PKBM Buana Mekar bertujuan meningkatkan dan memberikan layanan pendidikan bagi masyarakat sasaran melalui pengembangan berbagai aspek komponen sistem penyelenggaraan dan pembelajaran dalam rangka mencapai keunggulan komparatif maupun kompetitif. Penyelenggaraan diversifikasi layanan pendidikan yang berbasis keunggulan lokal melalui pembelajaran keterampilan fungsional atau vokasional untuk membekali warga belajar memiliki keterampilan yang secara fungsional dapat diterapkan dalam kehidupan untuk bekerja mencari nafkah maupun dalam rangka melanjutkan pendidikannya.

Dalam rangka mendukung pembelajaran tersebut dikembangkan silabus yang mencakup strategi, metode, media, alat, bahan belajar dan penilaian yang mengacu pada kurikulum yang disusun. Dukungan sarana pembelajaran dan sumber belajar yang dapat digunakan mencapai tujuan pembelajaran baik akademik maupun kecakapan hidup. Kemitraan baik dalam kerangka pembelajaran, maupun pendampingan menghubungkan lulusan dengan pasar kerja.

Namun yang paling penting agar program Kejar Paket $\mathrm{C}$ berjalan dengan baik, maka teknik identifikasi kebutuhan belajar warga belajar perlu mendapat perhatian mendasar. Identifikasi kebutuhan belajar secara menyeluruh yang dilakukan oleh perencana program Paket $\mathrm{C}$ bertujuan untuk meningkatkan motivasi warga belajar agar berpartisipasi aktif dalam pembelajaran. Selain itu identifikasi kebutuhan belajar dilakukan sebagai dasar penyusunan tujuan belajar.

Penentuan tujuan belajar mengandung arti merumuskan tujuan yang akan dicapai 
melalui kegiatan belajar. Tujuan ini penting untuk dirumuskan berdasarkan tiga alasan. Pertama, tujuan itu merupakan arah dari segala kegiatan belajar. Kedua, tujuan dijadikan dasar untuk pemilihan dan pengadaan unsur-unsur belajar yang tepat. Ketiga, tujuan itu adalah sebagai tolok ukur dalam evaluasi kegiatan belajar, dalam arti bahwa kegiatan belajar itu baik apabila hasil belajar itu telah membawa warga belajar kepada tujuan belajar yang telah ditetapkan. Secara umum dapat dikemukakan bahwa tujuan belajar itu merupakan tolok ukur yang menentukan untuk pemilihan sarana belajar, merinci isi atau materi pelajaran, mengembangkan kegiatan belajar, dan menyiapkan alat-alat evaluasi kegiatan belajar (Tyler dalam Sudjana, 2004).

Teknik-teknik yang dapat dipergunakan dalam melaksanakan identifikasi kebutuhan dan sumber belajar, sebagai acuan dalam penyusunan program kegiatan pembelajaran PNF dan pemberdayaan masyarakat, termasuk program Kejar Paket C. Identifikasi kebutuhan merupakan proses yang sangat kritis dalam mengelola suatu program PNF. Langkah ini sangat menentukan keberhasilan langkah selanjutnya, terutama dalam penyusunan program Kejar Paket C. Program ini merupakan salah satu upaya memecahkan masalah yang dihadapkan pada suatu lembaga yang berkaitan dengan kualitas sumber daya manusia (SDM) dalam masyarakat, organisasi atau lembaga. Penelitian ini bertujuan (1) mengidentifikasi rencana pembelajaran keterampilan fungsional yang akan diberikan kepada warga belajar, (2) mengidentifikasi proses pembelajaran keterampilan fungsional untuk meningkatkan pengetahuan, sikap dan keterampilannya di bidang wirausaha, (3) mengidentifikasi waktu pelaksanaan pembelajaran keterampilan fungsional, dan (4) mengidentifikasi sarana, peralatan dan media pembelajaran apa saja yang diperlukan dalam mendukung kelancaran proses pembelajaran.

\section{METODE}

Penelitian ini menggunakan pendekatan kualitatif untuk menggambarkan dan menganalisis fakta dengan interpretasi yang tepat terhadap teknik identifikasi program Kejar Paket C dalam meningkatkan keterampilan fungsional warga belajar di PKBM Buana Mekar Desa Mekar Buana Kecamatan Tegalwaru Kabupaten Karawang. Pendekatan ini menganalisis informasi tentang fenomena utama yang dieksplorasi dalam penelitian, partisipan penelitian, dan lokasi penelitian. Tujuan penelitian ini ditulis dengan istilahistilah "teknis" penelitian yang bersumber dari bahasa penelitian kualitatif (Schwandt, 2007 dalam Cresswell, 2013:167). Pendekatan ini digunakan karena lebih mudah apabila berhadapan dengan kenyataan, dan menyajikan secara langsung hakikat hubungan antara peneliti dengan responden, lebih peka dan lebih dapat menyesuaikan diri dengan banyak penajaman pengaruh bersama terhadap polapola nilai yang dihadapi (Moleong, 2004:5).

Metode yang digunakan dalam penelitian ini adalah studi kasus yang bertujuan memperoleh deskripsi kasus secara detail, analisis tema atau pokok bahasan, dan interpretasi peneliti atau penegasan kasus. Interpretasi ini dapat disebut "pelajaran yang dipelajari” (Guba \& Lincolin, 1989 dalam McMillan \& Schumacher, 1997). Melalui studi kasus ini peneliti berusaha mengungkapkan dan menganalisis data secara detail tentang teknik identifikasi program Kejar Paket C dalam meningkatkan keterampilan fungsional warga belajar di PKBM Buana Mekar. Subjek penelitian terdiri dari satu orang pengurus PKBM Buana Mekar dan tiga orang warga belajar Paket $\mathrm{C}$.

Teknik yang digunakan sebagai instrumen pengumpulan data adalah observasi, wawancara mendalam, dan analisis dokumentasi sebagai sumber data triangulasi metode dan sumber penelitian yang dapat dipertanggungjawabkan keakuratannya. Tahapan yang dilakukan dalam penelitian ini adalah (a) orientasi untuk mendapatkan informasi tentang apa yang penting untuk ditemukan, (b) eksplorasi untuk menentukan sesuatu secara terfokus, dan (3) tahap member check untuk mengecek temuan 
menurut prosedur dan memperoleh laporan akhir (Nasution, 1996).

Teknik analisis data yang digunakan adalah model interaktif melalui langkah-langkah (a) koleksi data (data collection), (b) reduksi data (data reductional), (c) penyajian data (data display) dan (d) penarikan kesimpulan/verifikasi (conclusion/verifying) (Miles \& Huberman, 1992).

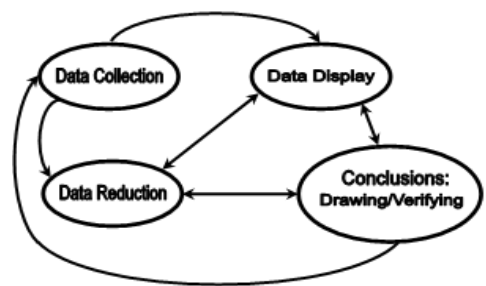

Gambar 1. Komponen Analisis Data Model Interaktif (Miles M.B \& Huberman A.M.,1992:20).

\section{HASIL DAN PEMBAHASAN}

\section{Teknik Identifikasi Kebutuhan Belajar Program Kejar Paket C}

Pada tahap awal program Kejar Paket C dilaksanakan dengan identifikasi. Identifikasi adalah cara menentukan sasaran warga belajar Kejar Paket C di PKBM Buana Mekar. Teknik identifikasi yang digunakan ini antara lain yaitu dengan menggunakan Kartu SKBM, wawancara, angket, observasi, pertemuan kelompok, teknik indikator sosial, dan mungkin gabungan dari beberapa teknik tersebut.

Tabel 1. Contoh Kartu Sistem Kebutuhan Belajar Masyarakat (SKBM)

\begin{tabular}{|c|c|}
\hline \multicolumn{2}{|c|}{ SKBM } \\
\hline Nama & \\
\hline Usia/Status & \\
\hline Pendidikan & \\
\hline Pekerjaan & ... \\
\hline Alamat & \\
\hline Saya ingin belajar keterampilan & Saya memiliki keterampilan \\
\hline 1. & 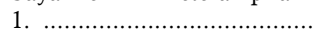 \\
\hline $2 . \quad$. & 2. \\
\hline
\end{tabular}

Salah satu bentuk teknik identifikasi yang digunakan kartu yang disebut dengan kartu Sistem Kebutuhan Belajar Masyarakat (SKBM) yang nampak pada tabel 1. Kartu SKBM ini dapat dibagi menjadi dua macam, yaitu kartu SKBM untuk sasaran calon warga belajar atau kelompok sasaran dan kartu SKBM untuk sasaran orangtua dan tokoh masyarakat (pimpinan formal dan informal).

Pengelola program Paket C dalam melaksanakan identifikasi yang dilakukan adalah; pertama, melakukan penyusunan pedoman identifikasi, yang berisi antara lain perumusan tujuan, menentukan teknik identifikasi yang akan digunakan, menentukan segi yang akan diungkap (nama, umur, jenis kelamin, status perkawinan, status pendidikan, pekerjaan, keterampilan yang dimiliki, hobby/kegemaran, kebutuhan yang dirasakan, sumber daya yang diperkirakan mendukung, sarana-prasarana yang tersedia, dan lainnya), menentukan petugas pelaksana identifikasi, menentukan waktu pelaksanaan dan merencanakan jumlah biaya. Kedua, penyusunan instrumen dibuat format-format yang diperlukan untuk mengungkap data yang diharapkan. Isi instrumen menyangkut aspekaspek kondisi daerah untuk mengungkap masalah yang ada sebanyak mungkin.

Pertimbangan-pertimbangan yang dapat dijadikan dasar dalam menentukan prioritas kebutuhan belajar, antara lain (1) menentukan kebutuhan (untuk tujuan apakah kita memilih); (2) mempertimbangkan pilihan kebutuhan yang tersedia (apakah pilihan dapat memenuhi tujuan dengan cara yang paling baik); dan (3) menilai risiko relatif dari pilihan yang tersedia (pilihan manakah yang mungkin paling aman atau paling produktif).

\begin{tabular}{llrr}
\multicolumn{2}{r}{ Contohnya } & seperti yang dikemukakan \\
salah seorang & warga belajar yang \\
mengemukakan, & bahwa & ketertarikannya \\
mengikuti Kejar Paket C & adalah untuk \\
menguasai & keterampilan & fungsional
\end{tabular}
perbengkelan. Karena merasa memiliki keahlian tambal ban yang diturunkan dari orangtuanya. Dengan adanya program Kejar Paket $\mathrm{C}$ berbasis keterampilan fungsional ini, Dia ingin mengembangkan keahliannya di bidang otomotif khususnya perbengkelan. Hal ini juga berkaitan dengan faktor jarak antara desa dengan kota cukup jauh dan juga akses jalan yang kurang begitu baik sehingga jika ada masyarakat sekitar yang ingin memperbaiki 
kendaraannya ke bengkel harus melalui jalan yang cukup jauh.

Identifikasi kebutuhan belajar, sumber, dan kemungkinan hambatan kegiatan Kejar Paket C dilaksanakan sebelum program berjalan. Identifikasi kebutuhan belajar merupakan hal yang sangat perlu karena suatu kegiatan belajar akan sangat bermanfaat bagi peserta bila yang diikutinya tersebut dapat memenuhi kebutuhan yang dirasakannya. Setelah mengetahui kebutuhan belajar, maka selanjutnya adalah mengidentifikasi sumber belajar yang tepat dengan kegiatan pembelajaran yang akan dilaksanakan. Sumber belajar yang diidentifikasi tersebut dapat berupa manusia dan dapat pula berupa non manusia.

Di samping mengidentifikasi kebutuhan dan sumber belajar yang mungkin dapat dimanfaatkan. Maka perlu diidentifikasi kemungkinan hambatan yang akan dihadapi atau dijumpai baik dalam melaksanakan kegiatan pengaruh kerjasama dalam situasi belajarnya, pembelajaran maupun dalam mengembangkan hasil pembelajaran. Kemungkinan hambatan ini dapat berupa faktor rnanusia seperti; keterbatasan kemampuan sumber belajar dalam memberikan dan menyajikan materi, ketidakmampuan peserta dalam mengembangkan keterampilan. Sedangkan faktor non manusia seperti, dukungan lingkungan sekitar, bantuan dari pihak lain berupa modal stimulan dalam mengembangkan keterampilan yang dimiliki.

Secara epistimologis, kajian tentang pembelajaran Kejar Paket C berbasis keterampilan fungsional di PKBM Buana Mekar dapat dilihat dalam pengembangan sistem, model dan pengelolaan pembelajaran. Dari segi sistem dapat dipahami bahwa pada umumnya pembelajaran memiliki komponen masukan lingkungan (environmental input), masukan sarana (instrumental input), masukan mentah (raw input), dan masukan lain (other input). Proses (processes) pembelajaran merupakan interaksi pembelajaran antara masukan sarana, terutama pelatih, dengan masukan mentah yaitu peserta pembelajaran. Tujuan pembelajaran terdiri atas tujuan pembelajaran antara keluaran (output), dan tujuan pembelajaran akhir yaitu pengaruh (outcome). "Pengaruh berkaitan dengan manfaat atau kegunaan pembelajaran yang telah diikuti peserta pembelajaran bagi dirinya, lembaga, masyarakat, dan lain sebagainya" (Sudjana, 2007:4).

Bila dikaitkan dengan pembelajaran partisipatif, bahwa teknik identifikasi merupakan tahap perencanaan. Seperti yang dikemukakan Sudjana (Kartika, 2011) dikemukakan bahwa pembelajaran partisipatif didasarkan pada prinsip-prinsip sebagai berikut: (1) identifikasi program pembelajaran dilakukan berdasarkan kebutuhan belajar (learning needs based). Sumber informasi tentang kebutuhan belajar adalah peserta atau calon peserta. Pentingnya kebutuhan belajar ini didasarkan atas asumsi bahwa peserta akan belajar secara efektif bila semua komponen program pembelajaran dapat membantu mereka untuk memenuhi kebutuhannya, (2) berorientasi pada tujuan kegiatan belajar (learning goals and objectives oriented). Tujuan pembelajaran disusun oleh sumber belajar bersama peserta, dengan mempertimbangkan pengalaman peserta, potensi yang dimiliki serta sumber-sumber yang tersedia di lingkungan kehidupan mereka serta kemungkinan hambatan-hambatan yang muncul dalam kegiatan pembelajaran, (3) berpusat pada peserta (participant centered). Peserta diikutsertakan dan harus berperan penting dalam kegiatan perencanaan, pelaksanaan dan evaluasi, dan (4) belajar berdasarkan pengalaman (experiential learning). Proses pembelajaran partisipatif disusun dan dilaksanakan dengan berangkat dari hal-hal yang telah dipelajari berupa pengetahuan, nilai dan keterampilan yang telah dimiliki peserta serta dari pengalaman peserta, baik dari pengalaman dalam tugas pekerjaan sehari-hari maupun pengalaman nyata yang diangkat dari tugas atau pekerjaan mereka. Oleh karena itu, pendekatan yang digunakan dalam proses pembelajaran lebih menitikberatkan pada pendekatan pemecahan masalah.

Dari prinsip-prinsip tersebut nampak adanya keterlibatan peserta dalam perencanaan (participatory planning), keikutsertaan dalam 
perencanaan pelaksanaan (participatory implementation) dan keikutsertaan dalam perencanaan evaluasi (participatory evaluation). Pelatih lebih berperan sebagai sumber belajar yang memfasilitasi peserta untuk mencapai tujuan pembelajaran, yaitu perubahan pengetahuan dan keterampilan. Peserta menjadi subyek yang berperan aktif sejak perencanaan, pelaksanaan hingga evaluasi pembelajaran.

Program Paket C di Desa Tanjungpakis Kecamatan Pakisjaya Kabupaten Karawang dilaksanakan dengan melibatkan warga belajar dalam merencanakan, melaksanakan dan menilai hasil pembelajaran keterampilan fungsional berwirausaha. Tujuan pembelajaran disusun untuk meningkatkan pengetahuan, keterampilan dan sikap kewirausahaan warga belajar Kejar Paket C yang berdampak pada peningkatan kesempatan kerja dan pemberdayaan atau kemandirian ekonomi warga belajar. Pembelajaran keterampilan fungsional berwirausaha berkaitan dengan pengetahuan, sikap dan keterampilan berwirausaha tentang cara mengolah bahan mentah menjadi bahan jadi, dan cara memasarkan hasil produksi. Untuk mengukur keberhasilan proses pembelajaran, tutor melaksanakan penilaian, baik teori dan kemampuan keterampilan berwirausaha warga belajar (Hidayat, 2016).

\section{Peningkatan Keterampilan Fungsional Belajar Kejar Paket C}

Hasil pembelajaran Kejar Paket C berbasis keterampilan fungsional di PKBM Buana Mekar memiliki aspek tujuan pembelajaran yang meliputi tiga ketegori, yaitu (1) ranah kognitif yang mencakup pengetahuan (knowledge), pengertian (comprehension), penerapan (application), analisis, sintesis, dan evaluasi, (2) afektif yang mencakup perubahan yang berhubungan minat, sikap, nilai-nilai, penghargaan dan penyesuaian diri, dan (3) keterampilan yang mencakup keterampilan produktif (productive skills), keterampilan teknik (technical skills), keterampilan fisik (physical skills), keterampilan sosial (social skills), keterampilan pengelolaan (managerial skills), dan keterampilan intelek (intellectual skills) (Bloom dalam Sudjana, 2004).

Gambaran salah seorang warga belajar mengemukakan bahwa ketertarikan untuk menguasai keterampilan fungsional otomotif bidang perbengkelan. Dengan adanya program Kejar Paket $\mathrm{C}$ berbasis keterampilan fungsional ini Dia ingin mengembangkan keahliannya di bidang perbengkelan dan bias memiliki bengkel sendiri. Setelah lulus program Kejar Paket C ini ingin melanjutkan ke perguruan tinggi di bidang otomotif. Prospek keahlian perbengkelan di wilayah desa sekitar sangat baik, karena jarak yang cukup jauh dan jalan yang tidak begitu baik sehingga cukup beralasan jika hendak mendirikan bengkel di wilayah itu.

Dari hasil analisis data menunjukkan hasil pembelajaran Kejar Paket $\mathrm{C}$ berbasis keterampilan fungsional di PKBM Buana Mekar ini lebih menekankan pada pengembangan kewirausahaan. Sikap dan keterampilan kewirausahaan merupakan tujuan utama proses pembelajaran Kejar Paket C ini. Suryana (2006:10) mengemukakan bahwa "Kewirausahaan adalah terjemahan dari "entrepreneurship", yang dapat diartikan sebagai "the backbone of economy", yaitu syaraf pusat perekonomian atau sebagai 'tailbone of economy', yaitu pengendali perekonomian suatu bangsa" (Suharto Wirakusumo dalam Suryana (2006:10).

Secara faktual hasil yang telah diperoleh warga belajar Kejar Paket C setelah mengikuti pembelajaran keterampilan fungsional berkaitan dengan ranah kognitif, afektif, dan keterampilan kewirausahaan. Hasil pengetahuan berkaitan dengan cara mengolah bahan mentah menjadi bahan jadi. Hasil keterampilan berkaitan dengan praktik keterampilan cara memasarkan hasil produksi. Hasil afektif berkaitan dengan tumbuh dan berkembangnya sikap kemandirian warga belajar dalam mengembangkan usahanya. Dampak pembelajaran keterampilan fungsional berwirausaha dapat membuka kesempatan bagi warga belajar untuk meningkatkan kemandirian ekonomi sehingga meningkatkan pendapatan keluarganya.

Secara etimologi kewirausahaan merupakan nilai yang diperlukan untuk 
memulai suatu usaha (start-up phase) atau suatu proses dalam mengerjakan suatu yang baru (creative) dan sesuatu yang berbeda (innovative). Dalam hal ini pengetahuan, sikap dan keterampilan kewirausahaan. Kewirausahaan adalah suatu proses melakukan sesuatu yang baru dan berbeda dengan tujuan menciptakan kemakmuran bagi individu dan memberi nilai tambah pada masyarakat (Winarto, 2004). “... entrepreneurship secara sederhana sering diartikan sebagai prinsip atau kemampuan wirausaha" (Soedjono, Meredith, Marzuki, dalam Alma, 2007:22). Kewirausahaan pada dasarnya merupakan jiwa diri seseorang yang diekspresikan melalui sikap dan perilaku yang kreatif dan inovatif untuk melakukan kegiatan berusaha. Orang yang memiliki jiwa kewirausahaan dapat melakukan kegiatan berusaha atau menjadi pelaku kewirausahaan atau lebih dikenal dengan sebutan wirausaha.

Selanjutnya Dale S. Beach dalam (Kamil, 2009:10) mengemukakan, "The objective of training is to achieve a change inthe behavior of those trained" (tujuan pembelajaran adalah untuk memperoleh perubahan dalam tingkah laku mereka yang dilatih). Melalui pembelajaran Kejar Paket $C$ berbasis keterampilan fungsional warga belajar diharapkan dapat meningkatkan perekonomian masyarakat di lingkungannya. Program Kejar Paket C berbasis keterampilan fungsional dilaksanakan untuk meningkatkan keterampilan berwirausaha warga belajar. Kewirausahaan adalah sikap dan perilaku wirausaha. Wirausaha ialah orang yang inovatif, antisipatif, inisiatif, pengambil resiko, dan berorientasi laba. Artinya "Kewirausahaan merupakan sikap dan perilaku orang yang inovatif, antisipatif, inisiatif, pengambil resiko, dan berorientasi laba" (John Kao dalam Sudjana, 2004:131).

Hidayat (2017) mengungkapkan penyelenggaraan program Paket $\mathrm{C}$ berbasis kewirausahaan banyak yang telah menunjukkan keberhasilan. Hasil pembelajaran menunjukkan peningkatan pengetahuan, sikap dan keterampilan kewirausahaan warga belajar Paket C di PKBM Bina Sejahtera Kabupaten Karawang. Hasil pembelajaran menunjukkan bertambahnya warga belajar Kejar Paket $\mathrm{C}$ yang memiliki sikap perilaku, pengetahuan sebagai wirausaha sekaligus memiliki keterampilan vokasi sablon dan printing sebagai jenis usaha, dan semakin banyaknya warga belajar yang mulai merintis usaha sablon dan printing dengan memanfaatkan keterampilannya, peluang usaha dan potensi di lingkungannya.

\section{SIMPULAN}

Identifikasi program Kejar Paket C bertujuan untuk mengidentifikasi rencana pembelajaran, proses pembelajaran, waktu pembelajaran, sarana, peralatan dan media pembelajaran apa saja yang diperlukan dalam mendukung kelancaran proses pembelajaran keterampilan fungsional di PKBM Buana Mekar. Teknik identifikasi antara lain menggunakan Kartu SKBM, wawancara, angket, observasi, pertemuan kelompok, teknik indikator sosial, dan mungkin gabungan dari beberapa teknik tersebut. Pada saat melaksanakan identifikasi beberapa pertimbangan yang dijadikan dasar penentuan prioritas kebutuhan belajar antara lain penentuan kebutuhan belajar yang dipilih, pertimbangan pilihan kebutuhan belajar yang tersedia, dan penilaian risiko relatif dari pilihan yang tersedia.

Hasil pembelajaran Kejar Paket C berbasis keterampilan fungsional di PKBM Buana Mekar menekankan pada pengembangan kewirausahaan. Pengetahuan kewirausahaan berkaitan dengan cara mengolah bahan mentah menjadi bahan jadi. Keterampilan kewirausahaan berkaitan dengan praktik keterampilan cara memasarkan hasil produksi. Sikap kewirausahaan berkaitan dengan tumbuh dan berkembangnya sikap kemandirian warga belajar dalam mengembangkan usahanya. Hasil ketiga aspek tersebut diharapkan berdampak terhadap terbukanya kesempatan bagi warga belajar Kejar Paket C meningkatkan kemandirian ekonomi keluarganya.

\section{DAFTAR PUSTAKA}

Alma, B. (2007). Kewirausahaan. Bandung: Alfabeta.

Cresswell, J. W. (2013). Research design. 
Yogyakarta: Pustaka Pelajar.

Hidayat, D. (2016). Pembelajaran partisipatif Moleong, L. J. (2004). Metode penelitian kualitatif. keterampilan berwirausaha untuk pemberdayaan ekonomi warga belajar kejar paket C. Jurnal Pendidikan Dan Pemberdayaan Masyarakat, 3(2), 122-137.

Hidayat, D. (2017). Pengelolaan pembelajaran berbasis kewirausahaan masyarakat program kejar paket C. Journal of Nonformal Education, 3(1), 1-10.

Kamil, M. (2009). Pendidikan nonformal. Bandung: Alfabeta.

Kartika, I. (2011). Mengelola pelatihan partisipatif. Bandung: Alfabeta.

McMillan, J. H., \& Schumacher, S. (1997). Research in education: A conceptual introduction. New York San Fransisco: Longman Inc.

Miles, M. B., \& Huberman, M. A. (1992).
Analisis data kualitatif. Jakarta: UI Press. Bandung: PT Remaja Rosdakarya.

Nasution, S. (1996). Metode penelitian naturalistik kualitatif. Bandung: Tarsito.

Sudjana, D. (2004). Pendidikan nonformal: Wawasan, sejarah perkembangan, filsafat, teori pendukung, asas. Bandung: Falah Production.

Sudjana, D. (2007). Manajemen program pendidikan untuk pendidikan luar sekolah dan pengembangan sumber daya manusia. Bandung: Falah Production.

Suryana, D. (2006). Kewirausahaan: Pedoman praktis (Kiat dan proses menuju sukses). Jakarta: Salemba Empat.

Winarto, P. (2004). First step to be an entrepreneur. Jakarta: Elex Media Komputindo. 